\title{
The significance of pre-existing, deeply weathered crystalline rock in interpreting the effects of glaciation in the Minnesota River valley, U.S.A.
}

\author{
C. J. Patterson, T.J. Boerboom \\ Minnesota Geological Survey, 2642 University Avenue, St. Paul, MN 55114-1057, U.S.A.
}

\begin{abstract}
Minnesota is largely underlain by Precambrian crystalline bedrock that was weathered to an average depth of $30 \mathrm{~m}$ prior to Late Cretaceous time. The fresh-rockweathered-rock interface is irregular, with as much as $45 \mathrm{~m}$ of relief. Weathering exploited joints, locally isolating meter-sized volumes of rock known as corestones. Variable amounts of residuum were removed through glaciation to leave (1) saprolite overlain by an in-situ Late Cretaceous soil profile; (2) partially eroded saprolite; and (3) undulating fresh rock surfaces (commonly mantled by rounded boulders) that display striae and glacial or fluvial polish.

Significant subglacial erosion of fresh bedrock is not required to form smoothly undulating bedrock surfaces with closed depressions; they may also form through removal of weathered bedrock and exposure of the weathering front. Large rounded boulders are not always shaped during transport; they may represent chemically rounded corestones resting at or near the bedrock source.

Unambiguous evidence for glacial erosion includes striae and streamlining of bedrock parallel to striae. Polish on rock can be created fluvially, and smoothed grooves and ridges in the rock may be chemically produced. Many rounded boulders found in glacial till and strewn on bedrock surfaces probably originated as corestones.
\end{abstract}

\section{INTRODUCTION}

Precambrian crystalline rock is well exposed in northeastern Minnesota, along the international border with Canada and in west-central Minnesota along the Minnesota River valley (Fig. 1). Elsewhere, Precambrian rock is buried by glacial sediment and Cretaceous and Paleozoic marine strata. Where buried by Cretaceous strata, the crystalline rock typically retains a thick weathering profile that developed on land prior to Late Cretaceous time (Parham, 1970). Where buried by Quaternary deposits alone, the saprolitic cap is partially eroded to a highly erratic preserved thickness that ranges from near zero to 60 or more meters.

The bedrock-dominated regions of Minnesota have been interpreted as glacial landscapes of areal scour, the bedrock differentially eroded relative to the strength of contrasting rock types. The control exerted by bedrock type and structure is evident in the shape and trend of hills and lakes, especially in the border-lakes region of northeastern Minnesota (Zumberge, 1952; Wright, 1972). It is difficult to assess how much glacial erosion has taken place. In principle, the main effect of glaciation can be merely the stripping away of previously weathered rock to reveal a chemically etched, fresh-rock surface. Glacial erosion of fresh rock may be limited to abrasion, predominantly on the stoss side of bedrock protuberances.

The hypothesis that chemical weathering, rather than glacial erosion, was the dominant geomorphological agent in creating weathered-shield areas has been proposed for Fennoscandia (Gjessing, 1967; Söderman, 1985; Kejonen and others, 1988; Lidmar-Bergström, 1988, 1989, 1995, 1997; Lundqvist,

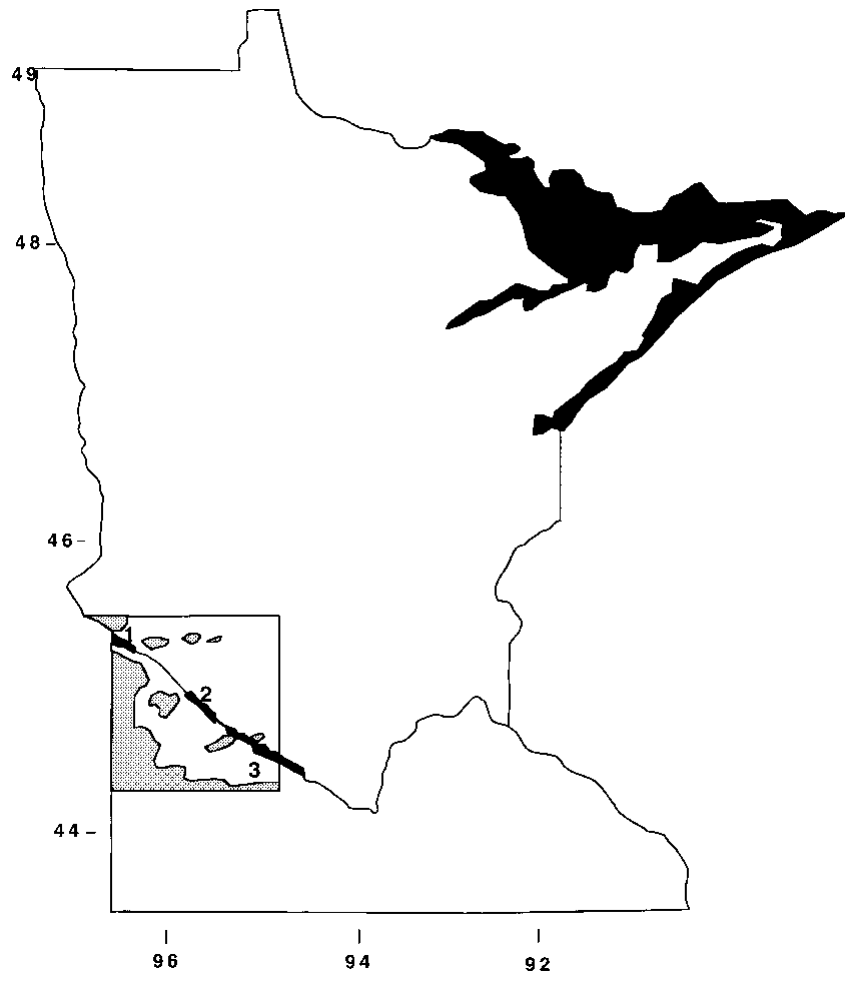

Fig. 1. Study area and site locations along Minnesota River valley. Precambrian bedrock exposure, black (adapted from Morey, 1981); areas where Precambrian rock is overlain by subcrop of Upper Cretaceous units, gray ( adapted from Patterson, in press). 
1988; Lidmar-Bergström and others, 1997), Britain (Hall and Sugden, 1987; Sugden, 1989) and North America (Feininger, 1971; Lehr and Hobbs, 1992). It is well supported by comparisons to areas of tropical weathering that have never been glaciated (e.g. Feininger, 1971; Lidmar-Bergström, 1989; Thomas, 1994).

A buried subsaprolite surface (the weathering front) is developed under tropical conditions. It is characterized by: (l) undulating relief and significant overdeepenings, due to the progression of chemical weathering irrespective of base level (Thomas, 1966; Feininger, 1971; Lidmar-Bergström, 1989); (2) roche moutonnée like forms (von Engeln, 1937; Linton, 1955; Lindström, 1988; Lidmar-Bergström, 1988); (3) rounded bedrock overhangs (Lidmar-Bergström, 1989); (4) stepped bedrock surfaces with overdeepenings (Bakker, 1965; Feininger, 1971); (5) cavernous weathering forms (Kejonen and others, 1988); and (6) small weathering pits (Twidale and Bourne, 1975). In the overlying saprolite, rounded boulders (corestones) can develop in situ (Ruxton and Barry, 1957; Ollier, 1969). Removal of the saprolite reveals a smoothly undulating bedrock surface, with rounded bedrock knobs and closed depressions scattered with well-rounded boulders. Such a surface can be misinterpreted as having been extensively scoured by ice, with the boulders transported in from a distant source.

By comparing three exposures along the Minnesota River valley (Fig. 1), we develop the hypothesis that glacial erosion in parts of the Canadian Shield in Minnesota was limited to the removal of weathered crystalline rock. The crystalline bedrock in these exposures (1) has been stripped and glacially striated; (2) has been stripped after glaciation by meltwater, but has not been in direct contact with glacial ice; and (3) has not been stripped and retains the saprolite cover. The geomorphological similarity of these three areas implies that chemical weathering was the principal influence on shaping the crystalline bedrock surface.

\section{GENERAL DESGRIPTION OF STUDY AREA}

The Precambrian rocks exposed in the Minnesota River valley form the southern edge of the Superior Province of the Canadian Shield and are an Archean gneiss terrane composed of four distinct blocks of quartzofeldspathic gneiss and granitoid intrusions (Southwick and Chandler,
1996). Weathering penetrated to an average depth of $30 \mathrm{~m}$, but the fresh-rock-weathered-rock interface is irregular and undulates with as much as $45 \mathrm{~m}$ of relief (Parham, 1970; Setterholm and Morey, 1989). Where preserved, the upper part of the weathering profile displays soil development in the form of a pisolitic lateritic clay. The profile underlies Cretaceous marine sedimentary rocks, which led to its preservation in much of the western part of the state (Fig. 1; Setterholm and Morey, 1989).

\section{GLAGIAL HISTORY}

Although the study area was repeatedly glaciated during the Pleistocene, it was also a site of glacial erosion, especially during late-Wisconsinan ice advances. The truncated remains of much older glacial units are unconformably overlain by late-Wisconsinan surficial glacial sediments. In places, the lowest glacial sediment directly overlies fresh crystalline rock, suggesting that the earliest glacial advances locally eroded through the Cretaceous marine sedimentary rocks and saprolite (Patterson, 1997; Patterson and others, 1999).

The surficial glacial sediment in the Minnesota River basin was deposited by the late-Wisconsinan Des Moines lobe (Fig. 2a; Matsch, 1972), which advanced repeatedly (Patterson, 1997). It was during an advance of the Des Moines lobe that the granite at sites la, b, and c (Fig. l) was last striated, as inferred from striae orientations and a preliminary interpretation of cosmogenic-isotope dating of the striated surface (personal communication from P. Bierman, 1998). The granite outcrops were probably then shallowly buried by glacial sediment before final exhumation by meltwater.

An ice advance to the Big Stone moraine dated at 12 kyr BP terminated just north of site la (Fig. 2b). A large proglacial lake, Glacial Lake Agassiz, began to form as the ice retreated from the Big Stone moraine (Fig. 2c). For much of its existence, the lake was drained by Glacial River Warren, which flowed southeast from the southern tip of the lake (Upham, 1883, 1896; Matsch and Wright, 1967). It was during the incision of River Warren that the striated bedrock at sites la, b, and $\mathrm{c}$ and the unstriated bedrock at sites $2 \mathrm{a}$ and b were exposed. Site 3 is not within the River Warren channel and the crystalline rock here has never been exposed; it remains $63 \mathrm{~m}$ below the surface.
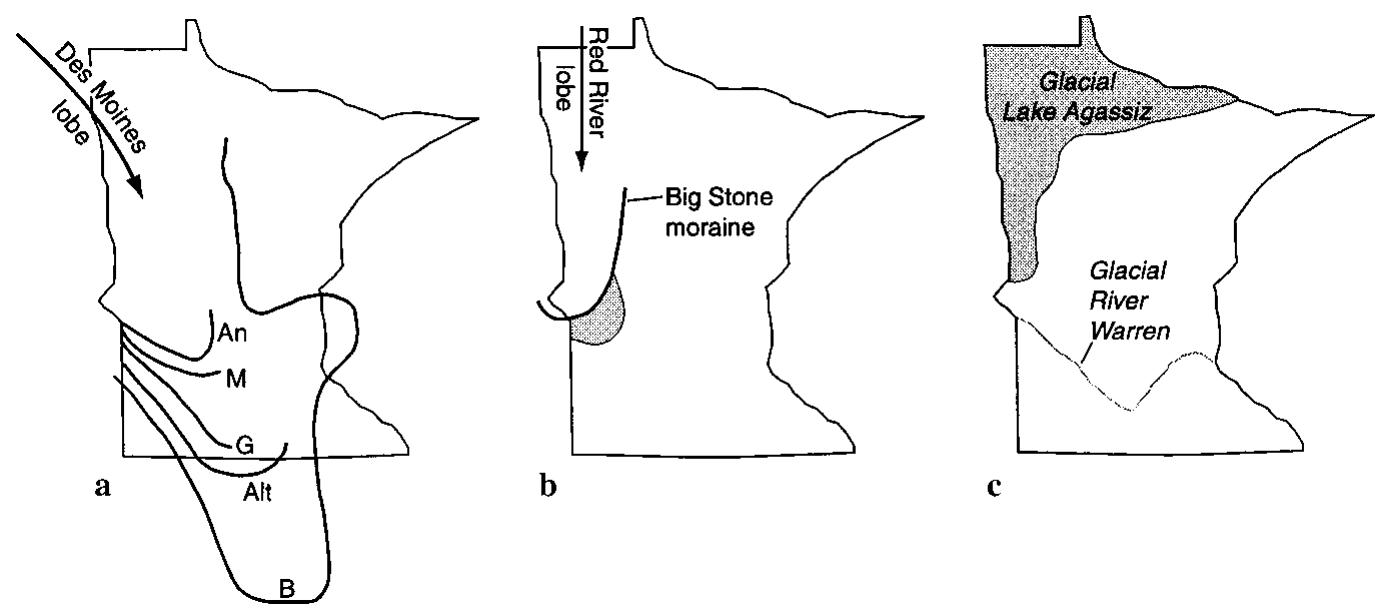

Fig. 2. General glacial geology of Minnesota: (a) moraines of the Des Moines lobe; (b) location of the Big Stone moraine and Glacial Lake Benson; (c) Glacial Lake Agassiz and Glacial River Warren, current trace of Minnesota River (adapted from Patterson and others, 1999). 


\section{SITE DESGRIPTIONS}

\section{Sites $1 \mathrm{a}, \mathrm{b}$, and $\mathrm{c}$}

Three localities that comprise site 1 were grouped because of proximity and similarity of bedrock type and exposure history. The largest area of outcrop, site la, best displays the undulating relief of the bedrock surface (Fig. 3). The granite is exposed in an upper terrace of River Warren from $304 \mathrm{~m}$ to $317 \mathrm{~m}$ a.s.l., a local high on the crystalline bedrock topography.

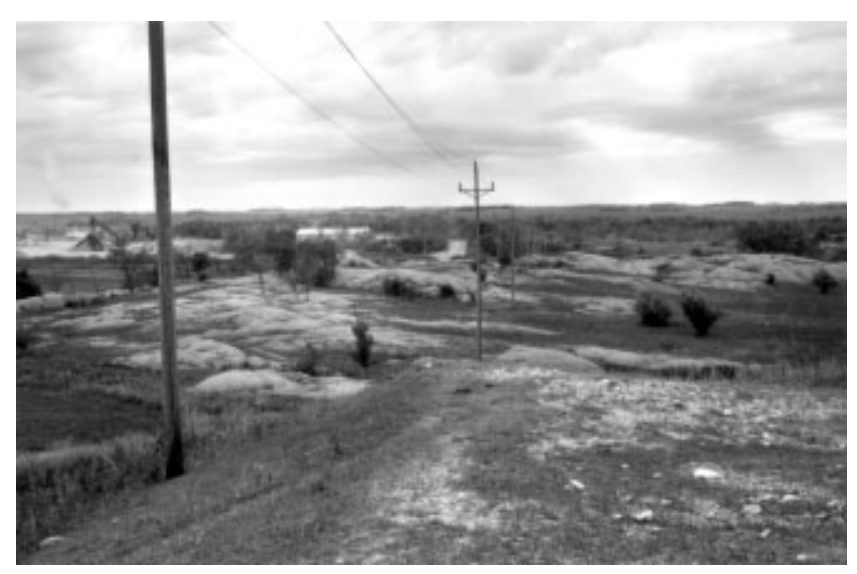

Fig. 3. Site 1a. Most extensive outcrop area, showing undulating nature of bedrock surface. View to south; ice advanced from the west (right).

Striae on the outcrops trend N40W to N35W (personal communication from D. L. Southwick, 1997). The steep, irregular bedrock outcrops are weakly streamlined in a similar direction. However, the linear shape of the outcrops is most likely inherited from bedrock structure. Brittle fractures oriented N30-50W and another orthogonal set oriented N55E control the shape of the outcrops. The outcrops are littered with rounded boulders of the same lithology.

At site 1b, bedrock crops out from 293-317 $\mathrm{m}$ a.s.l. in an upper terrace of River Warren. This outcrop is also a local crystalline bedrock high. The outcrop shape reflects the dominant lithologic fabric of the gneissic rock. Striae on the outcrops are oriented N18W (personal communication from D.L. Southwick, 1997) and N50W. They may reflect

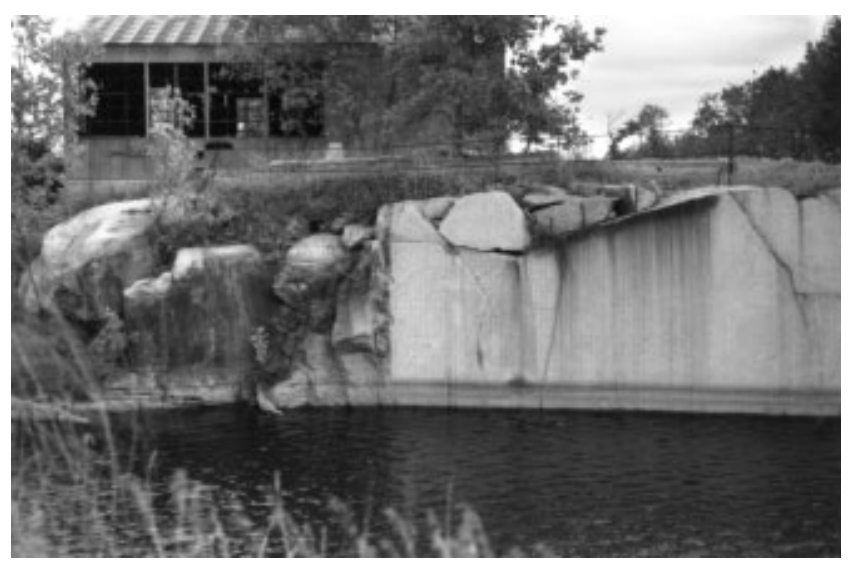

Fig. 4. Site 1b. Weathering, as seen in the quarry wall, has progressed along joints, isolating rounded-bedrock blocks. more than one ice-flow event or local variations in ice-flow direction around the bedrock protuberance. Vertical-cut faces in an abandoned quarry at site lb show how weathering has progressed along orthogonal joint sets and has begun rounding the joint-isolated blocks (Fig. 4). In another area of the quarry, recent sheeting of about a decimeter of rock has produced a parabolic bedrock surface of steep sides and rounded top that at first appears to have been glacially moulded (Fig. 5). However, the surface is not polished, but fresh, rough, and granular; sheeting probably occurred as the stone was being quarried, or shortly thereafter.

Site lc is a low-lying outcrop (293-296 $\mathrm{m}$ a.s.l.) along the valley wall of an upper terrace of River Warren, part of the same bedrock high as site lb. Two small areas of striae (Fig. 6) on the outcrop trend N40W and N80W, again reflecting either minor variations in ice-flow direction or different iceflow events. The long axes of the outcrops are roughly orthogonal to this trend, controlled by either joints, lithologic fabric, or both. This low, smooth outcrop has rounded overhangs (Fig. 7) and is strewn with rounded boulders of the same granite type. One area displays shallow weathering pits (Fig. 8).

\section{Sites $2 a$ and $b$}

Site 2 consists of two areas of outcrop that were exposed by River Warren. In site 2a, fractured granitic gneiss with horn-

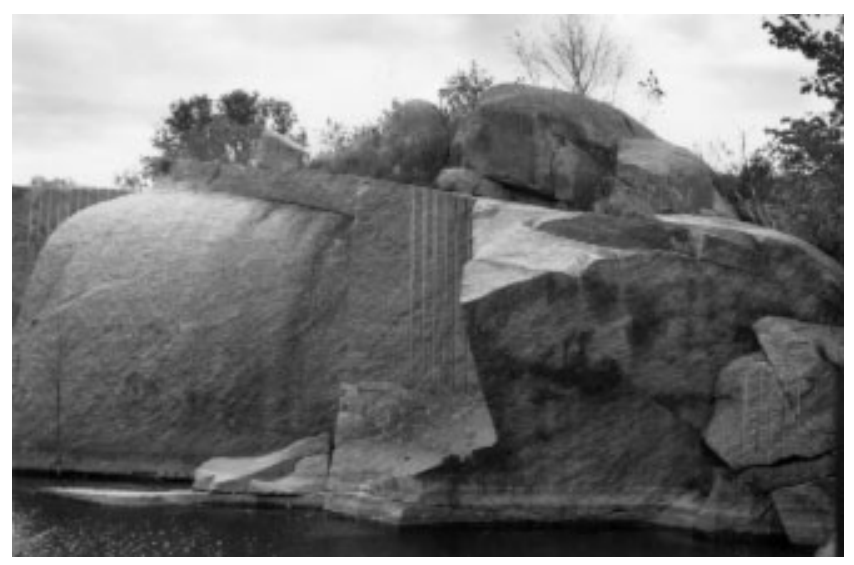

Fig. 5. Site 1b. Recent sheeting of granite resulting from quarrying that has exposed a fresh, parabolic rock surface.

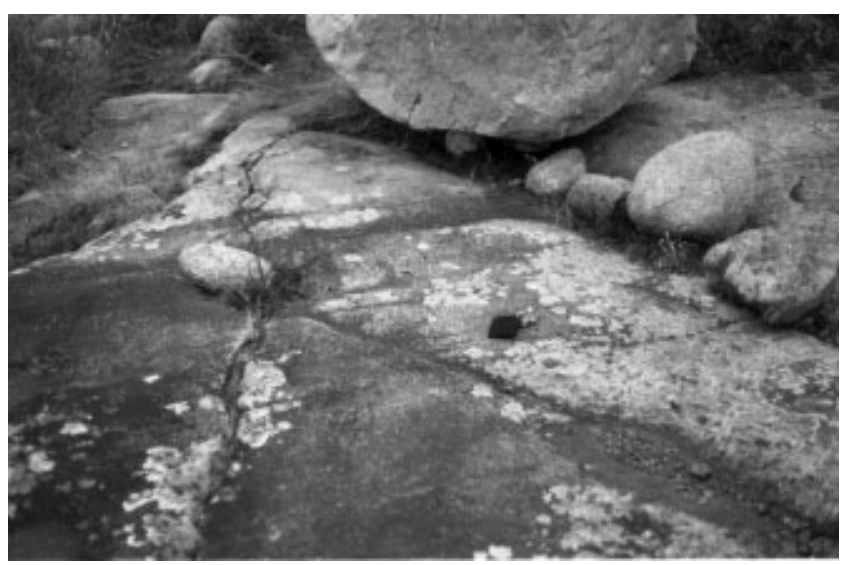

Fig. 6. Site 1c. One of two small areas of striae; also note rounded boulders. Striae are unambiguously glacial in origin. Boulders may have been rounded chemically; their lithology is identical to that of the outcrop. 


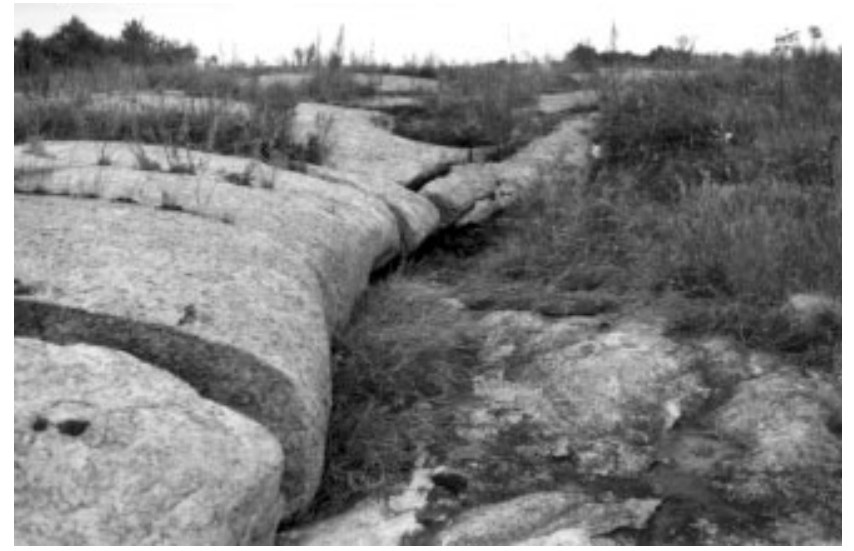

Fig. 7. Site 1c. Rounded bedrock overhang interpreted as a result of chemical weathering along joints.

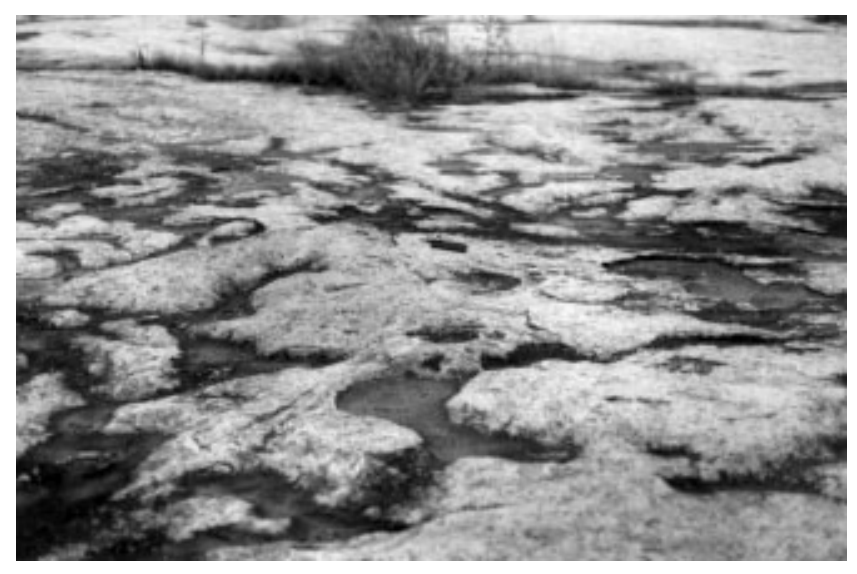

Fig. 8. Site 1c. Shallow pits in rock surface interpreted as weathering pits, possibly even postglacial in age.

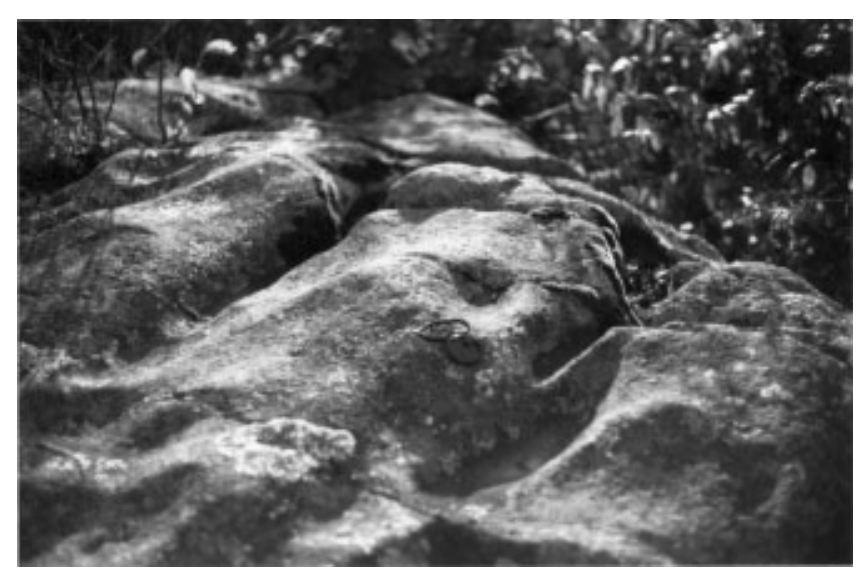

Fig. 9. Site 2a. Shallow scour on outcrop tops interpreted as fluvially modified weathering pits.

blende andesite dikes (Southwick and Patterson, 1998) is exposed from 284-305 $\mathrm{m}$ a.s.l. in the valley bottom. The dikes are more resistant to weathering, and their generally eastwest trend is easily recognized. The irregular bedrock surface has many closed depressions, some of which are partly filled with river sediment. The imprint of fluvial erosion is apparent in the deep, vertical potholes and shallow scours on outcrop tops (Fig. 9). The scours may have originated as weathering pits, but they have been modified by flowing water.

Site $2 \mathrm{~b}$ is also located in the valley bottom. Here, granite

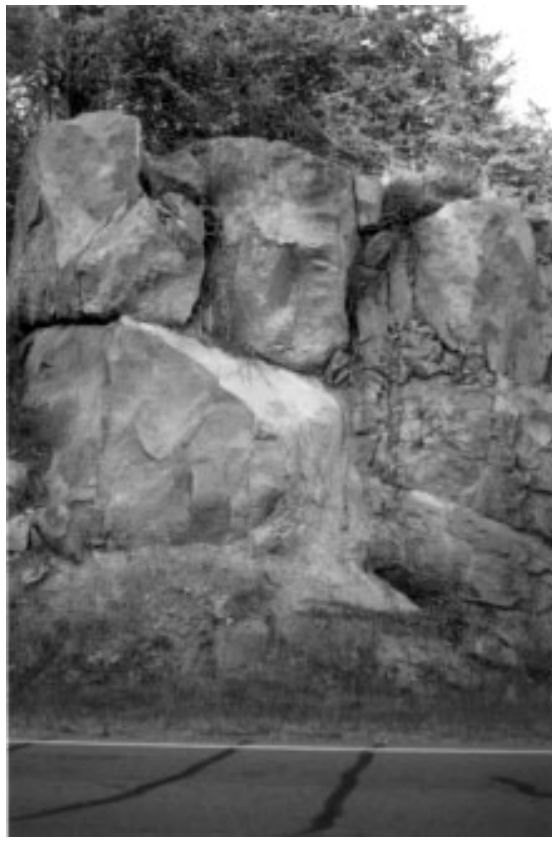

Fig. 10. Site 2b. Road cut exposes 2-3m of weathered rock in the tail of an east-trending bedrock ridge, $1 \mathrm{~km}$ long.

with zones displaying more gneissic fabric crops out from $280 \mathrm{~m}$ to $299 \mathrm{~m}$ a.s.l., another local bedrock high. In nearby shallow-to-bedrock areas, large rounded "boulders" are more likely in-situ bedrock knobs that have been stripped of weathered-rock fragments. The long axes of outcrops are oriented northwest and east-northeast, probably reflecting structural control. A shallow road cut in the tail of a bedrock outcrop, $1 \mathrm{~km}$ long, shows that the upper $3 \mathrm{~m}$ of bedrock is composed of interlocking, chemically rounded blocks having weathered rock along the joints (Fig. 10). Downstream areas of kaolinitic saprolite were protected by bedrock knobs from fluvial erosion.

\section{Site 3}

Although northeast of site 3 bedrock crops out in the river valley from 256-268 $\mathrm{m}$ a.s.l., site 3 itself is in the sub-surface. Test holes that were drilled to study the resource potential of buried kaolin have allowed contouring of the bedrock surface in $20 \mathrm{ft}$ (about $6 \mathrm{~m}$ ) intervals (Fig. 11; Setterholm and others, 1989). The contour map shows that the fresh-rock surface (the weathering front) is rounded and undulating with as much as $40 \mathrm{~m}$ of relief and is similar in appearance to nearby exposures. Bedrock in the valley floor is at about the same elevation, but appears to have steeper slopes that form narrower crests than the sub-surface topography. This is likely an artifact of the test-hole density and the assumptions made while interpolating between data points when contouring. The stratigraphy is exemplified by a hole drilled in the area that penetrated $13 \mathrm{~m}$ of glacial sediment, $13.7 \mathrm{~m}$ of Cretaceous strata, and $39 \mathrm{~m}$ of saprolite before encountering fresh crystalline rock at approximately $244 \mathrm{~m}$ a.s.l.

\section{DISGUSSION}

Recent articles noting the preservation of fragile glacial landscapes that survived subsequent glaciation (e.g. Kleman, 1994) suggest that some areas of the glacier bed can survive repeated glaciation with no significant erosion. It is import- 


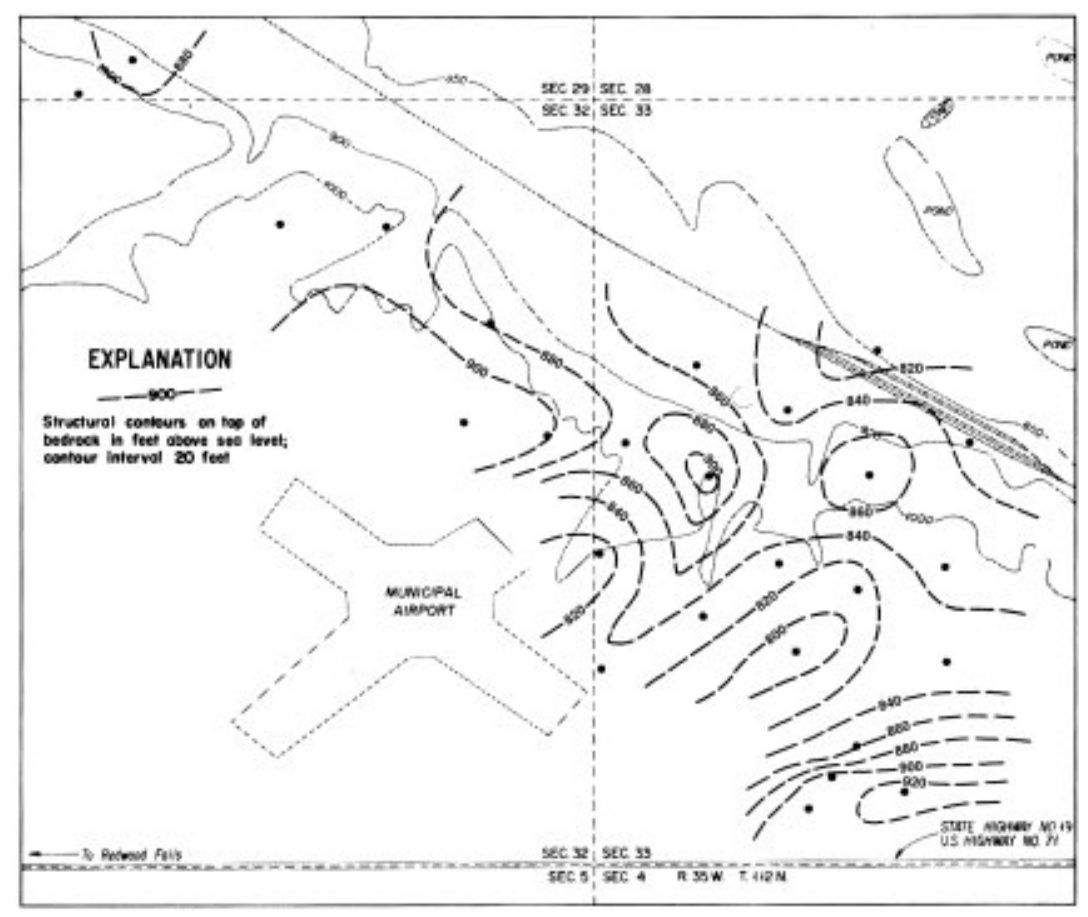

Fig. 11. Topography of the weathering front in the Precambrian bedrock surface, Redwood Falls area, Minnesota River valley, mapped by D.W. Lindgren (from Setterholm and others, 1989); bullets show test-hole locations.

ant to separate the pre-existing effects of weathering from glacial erosion so the efficacy of glacial erosion is not overestimated. This is especially critical if the glacial landscape is used to infer the nature of subglacial processes for the purpose of modeling glacier flow (e.g. Sugden, 1978; Clark and Pollard, 1998). The force required to remove loose grus from a surface is considerably different than that required to pluck and abrade fresh crystalline rock.

The three sites of bedrock exposure along the Minnesota River were chosen for their range of erosional histories in order to qualitatively evaluate the relative effect of chemical vs glacial erosion. Despite differences in rock type and exposure history, all three bedrock sites resemble each other in general morphology. The rock surfaces appear to have been shaped mainly by chemical weathering processes that took place while the surface was buried beneath a saprolite cover.

It is likely that glacial erosion had a more pronounced effect on the crystalline rock surface in northeastern Minnesota, where the Cretaceous marine strata were absent or thinner and glacial erosion could have exposed the surface earlier in the Pleistocene. This is also probably true for areas of the Canadian Shield in Canada, where the ice covered the area more continuously during the Pleistocene. But in the Minnesota River valley, where the bedrock was only recently subjected to subglacial and fluvial erosion, and where ice of at least the last advance was thin and the advances short-lived, the effects appear to be only a minor overprinting of the effects of chemical weathering.

\section{CONGLUSIONS}

In the upper Minnesota River valley, glacial advances have only eroded deep enough locally to expose the fresh Precambrian crystalline rock surface. Along the river valley, late- and post-glacial fluvial erosion have exposed the crystalline rock surface, in some cases for the first time. Elsewhere, the crystalline rock is buried and the complete stratigraphy, where preserved, includes a thick weathering residuum capped by Cretaceous marine strata overlain by varying thicknesses of glacial sediment. The features of these outcrops that we believe were inherited from chemical weathering include: (1) the smoothly rounded surface of the rock; (2) the steep sides; (3) closed depressions at all scales; (4) large linear grooves or highs, especially where aligned with structural or lithologic features such as joints, gneissic fabric, or dikes; and (5) rounded boulders of composition similar to the outcrops. Features of these outcrops that are most likely related to subglacial erosion include: (1)striae; (2) streamlining of the rock in a direction parallel to striae, but only convincingly glacial in origin if not parallel to structural control; and (3) polishing. However, polishing has been noted on the interior of potholes and in these locations, as well as on level rock surfaces, the polish has been created fluvially, not glacially. These sites serve as a caution to casual interpretation of exposed, undulating crystalline rock surfaces as due to glacial scouring. Care must be taken when incorporating evidence of subglacial erosion and bed conditions into models of glacier flow to avoid overestimating processes such as bedrock plucking, differential abrasion, and subglacial fluvial erosion.

\section{REFERENGES}

Bakker, J. P. 1965. A forgotten factor in the interpretation of glacial stairways: an old question; new problems. Z. Geomorphol., 9, 18-34.

Clark, P. U. and D. Pollard. 1998. Origin of the middle Pleistocene transition by ice sheet erosion of regolith. Paleoceanography, 13(1), 1-9.

Feininger, T. 1971. Chemical weathering and glacial erosion of crystalline rocks and the origin of till. U.S. Geol. Surv. Prof. Pap. 750-C, 65-81.

Gjessing, J. 1967. Norway's paleic surface. Nor. Geogr. Tidsskr., 21, 69-132.

Hall, A. M. and D. E. Sugden. 1987. Limited modifications of mid-latitude landscapes by ice sheets: the case of northeast Scotland. Earth Surf. Processes Landforms, 12(5), 531-542.

Kejonen, A., S. Keilosto and S. I. Lahti. 1988. Cavernous weathering forms in Finland. Geogr. Ann., 70A(4), 315-322.

Kleman, J. 1994. Preservation of landforms under ice sheets and ice caps. 
Geomorphology, 9(1), 19-32.

Lehr, J. D. and H. C. Hobbs. 1992. Glacial geology of the Laurentian divide area, St. Louis and Lake counties, Minnesota. St. Paul, MN, Minnesota Geological Survey. (39th Midwest Friends of the Pleistocene Field Trip, Biwabik, Minnesota. Guidebook Series 18.)

Lidmar-Bergström, K. 1988. Preglacial weathering and landform evolution in Fennoscandia. Geogr. Ann., 70A(4), 273-276.

Lidmar-Bergström, K. 1989. Exhumed Cretaceous landforms in south Sweden. Z. Geomorphol., Supplementband 72, 21-40.

Lidmar-Bergström, K. 1995. Relief and saprolites through time on the Baltic Shield. Geomorphology, 12, 45-61.

Lidmar-Bergström, K. 1997. A long-term perspective on glacial erosion. Earth Surf. Processes Landforms, 22, 297-306.

Lidmar-Bergström, K., S. Olsson and M. Olvmo. 1997. Palaeosurfaces and related saprolites in southern Fennoscandia. In Widdowson, M., ed. Palaeosurfaces: recognition, reconstruction and interpretation. London, Geological Society, 95-123. (Special Publication 120.)

Lindström, E. 1988. Are roches moutonnées mainly preglacial forms? Geogr Ann., 70A(4), 323-331.

Linton, D. L. 1955. The problem of tors. Geogr. F., 120(4), 470-487.

Lundqvist, J. 1988. The Revsund area, central Jämtland - an example of preglacial weathering and landscape formation. Geogr. Ann., $\mathbf{7 0 A}(4)$, 291-298.

Matsch, C. L. 1972. Quaternary geology of southwestern Minnesota. In Sims, P. K. and G. B. Morey, eds. Geology of Minnesota: a centennial volume. St. Paul, MN, Minnesota Geological Survey, 548-560.

Matsch, C. L. and H. E. Wright, Jr. 1967. The southern outlet of Lake Agassiz. In Mayer-Oakes, W. J., ed. Life, land and water. Proceedings of the 1966 Conference on Environmental Studies of the Glacial Lake Agassiz Region. Winnipeg, Man., University of Manitoba Press, 121-140. (University of Manitoba, Department of Anthropology. Occasional Paper 1.)

Morey, G. B. 1981. Geologic map of Minnesota: bedrock outcrops. St. Paul, MN, Minnesota Geological Survey. (State Map S-10, scale 1:3,168,000.)

Ollier, C. D. 1969. Weathering. London, Longman.

Parham, W. E. 1970. Clay mineralogy and geology of Minnesota's kaolin clays. St. Paul, MN, Minnesota Geological Survey. (Special Publication SP-10.

Patterson, C.J. 1997. Quaternary geology of southwestern Minnesota. In Patterson, C. J., ed. Contributions to the geology of southwestern Minnesota. St. Paul, MN, Minnesota Geological Survey, 1-45. (Report of Investigations 47.)

Patterson, C. J., A. R. Knaeble, S. E. Gran and S. Phippen. 1999. Regional hydrogeologic assessment of the upper Minnesota River basin, Minnesota. St. Paul, MN, Minnesota Geological Survey. (Regional Hydrogeologic Assessment RHA-4, Part A, Plate 1, scale 1:100,000.)

Ruxton, B. P. and L. Barry. 1957. Weathering of granite and associated erosional features in Hong Kong. Geol. Soc. Am. Bull., 68, 1263-1292.

Setterholm, D. R. and G. B. Morey. 1989. An extensive pre-Cretaceous weathering profile in east-central and southwestern Minnesota. U.S. Geol. Surv. Bull. 1989-H.

Setterholm, D. R., G. B. Morey, T.J. Boerboom and R. C. Lamons. 1989. Minnesota kaolin clay deposits: a subsurface study in selected areas of southwestern and east-central Minnesota. Minn. Geol. Surv. Inf. Circ. 27.

Söderman, G. 1985. Planation and weathering in eastern Fennoscandia. Fennia, 163(2), 347-352.

Southwick, D. L. and V.W. Chandler. 1996. Block and shear-zone architecture of the Minnesota River valley subprovince: implications for Late Archean accretionary tectonics. Can. 7. Earth Sci., 33, 831-847.

Southwick, D. L. and C. J. Patterson. 1998. Archean and Quaternary geology of the Minnesota River valley. In 44th Annual Meeting, Institute of Lake Superior Geology, 1998, Minneapolis, Minnesota. Proceedings. Vol. 2. St. Paul, MN, Minnesota Geological Survey, 133-168.

Sugden, D. E. 1978. Glacial erosion by the Laurentide ice sheet. F. Glaciol., 20 (83), 367-391.

Sugden, D. E. 1989. Modification of old land surfaces by ice sheets. Z Geomorphol., Supplementband 72, 163-172.

Thomas, M. F. 1966. Some geomorphological implications of deep weathering patterns in crystalline rocks in Nigeria. Inst. Br. Geogr. Trans., 40, 173-193.

Thomas, M. F. 1994. Geomorphology in the tropics. A study of weathering and denudation in low latitudes. Chichester, Wiley.

Twidale, C. R. and J. A. Bourne. 1976. Origin and significance of pitting in granitic rocks. Z. Geomorphol., 20 (4), 405-416.

Upham, W. 1883. The Minnesota Valley in the Ice Age. Am. Assoc. Adv. Sci. Proc., 32, 213-231.

Upham, W. 1896. The glacial Lake Agassiz. U.S. Geol. Surv. Monogr. 25.

Von Engeln, O. D. 1937. Rock sculpture by glaciers: a review. Geogr. Rev., $27(3), 478-482$.

Wright, H. E., Jr. 1972. Physiography of Minnesota. In Sims, P. K. and G. B. Morey, eds. Geology of Minnesota: a centennial volume. St. Paul, MN, Minnesota Geological Survey, 561-578.

Zumberge, J. H. 1952. The lakes of Minnesota: their origin and classification. Minn. Geol. Surv. Bull. 35. 